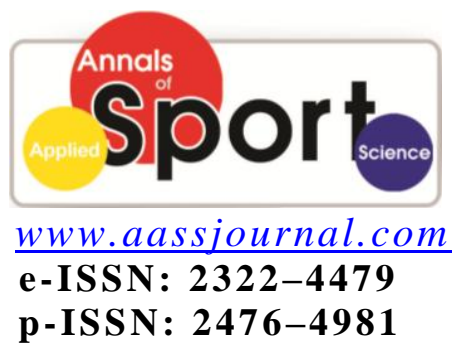

Shart Comomaunieution

Received: 10/01/2015

Accepted: 08/07/2015

\title{
The Relationship between Communication Skills with Aggression and Perfectionism of Lifeguards
}

\section{${ }^{1}$ Abbas Khodayari, ${ }^{2}$ Farideh Hadavi, ${ }^{1}$ Mohammad Javad Barzegar Mohammadi* $^{*}$}

1. Department of Sport Management, Faculty of Physical Education and Sport Science, Karaj Branch, Islamic Azad University, Karaj, Iran.

2. Department of Sport Management, Faculty of Physical Education and Sport Science, Islamshahr Branch, Islamic Azad University, Islamshahr, Iran.

\begin{abstract}
The purpose of the present study was to determine the relationship between aggression and perfectionism with communication skills of male lifeguards in Tehran. For this purpose, 300 qualified lifeguards from which 169 persons were selected as the study sample. In order to conduct this study, Aggression Questionnaires (Buss and Perry 1992), Positive and Negative Perfectionism Questionnaire (Terry-Short et al., 1995), Communication Skills Questionnaire (Stacey et al. 2006) were used. The results of the study showed that there is no relationship between aggression and its subscales with communication skills, except with hostility ( $\mathrm{r}=0.169$, $\mathrm{p}<0.05)$. The study also showed that there is no relationship between positive and negative perfectionism and communication skills' components, except between positive perfectionism with audio communication skills $(\mathrm{r}=-0.194, \mathrm{p}<0.05)$; and there are no multiple correlations between aggression and perfectionism with communication skills of male lifeguards in Tehran. It is concluded that proper use of aggression, perfectionism and communication skills can be used in identifying and selecting lifeguards.
\end{abstract}

Key Words: Aggression, Perfectionism, Communication Skills, Lifeguards.

Corresponding Author:

Mohammad Javad Barzegar Mohammadi

E-mail: m.barzegar60@yahoo.com 


\section{INTRODUCTION}

Connolly et al. (2010) declared aggression as a universal problem among all peoples, and do not consider it specific to a particular culture and society (1). What attract researchers' attention to an aggressive behavior are its undesirable effects on interpersonal behavior and also its unpleasant effects on an individual's internal states. Often an aggressor does not have the power to control his aggressive behavior and violates traditions and ethics of the society in which they live (1). Aggression is usually due to failure to achieve a goal or inappropriate behavior such as insults, injury or fear without cause. Generally, people behave aggressively due to negligence or failure to perform duties. When people reach the age of adolescence and youth, the main source of aggression changes from psychological origin to social limitations. Factors that affect adult aggression are opinion, disapproval, deprivation, exploitation and humiliation (2). In addition to unbearable psychological stress in exercise, athletes due to having specific psychological characteristics may be more at risk of deterioration. Among these psychological characteristics, perfectionism can be noted. A review of research suggests that professional athletes who show perfectionism tendencies in terms of character are without discipline, have poor cognitive restructuring strategies and organize exercise of their choice and these factors weakens them and reduce their autonomy and for this reason, are most vulnerable to deterioration (3). Regarding communication channel and how you think and feel, you can improve your feedback by discussing the pros and cons and removing the main ideas while making decision on your chosen path. Interpersonal communication is when you're connected with each other. Usually it is with someone else, but sometimes it can be more than one person. Again, all the processes of communication are used. Building a positive interpersonal relationship results in creating a successful work environment. The relationship between small groups is when a number of people meet each other. The group should be small enough so that all members are able to interact (4). Moment distraction, mental imbalance and reduced brain transmission speed in a lifeguard are due to fatigue and mental adversity. When a lifeguard does not have necessary mental relaxation and is constantly thinking about problems and how to deal with them during work, the possibility of incidences of aggression increases which causes decreased focus in lifeguards and not achieving their main objective which is to protect and save human lives. However, the problem can be overcome with training and improving the aquatic environments. The present study aims to investigate if there is a relationship between aggression and perfectionism with communication skills of male lifeguards in Tehran? Nazari, Dadkhah, and Yektayar (2013) showed that there is a direct relationship between transformational and commutative leadership style and communication skills (5). Ashrafi and Monjezi (2013) showed that communication skills' training has been effective on decreased aggression in high school female students in post-test and follow-up. The results of subscales of aggression also showed that communication skills' training in aspects of anger and nervousness, aggression, insults, obstinacy and malice have also been effective on decreased aggression (6). Ybrandt and Armelius (2010) considered self-confidence important in acceptance and rejection of problems and aggression between peers. The study that was conducted as a self-report among 204 Swedish adolescents 16 - 12 year-olds showed that adolescents who had more selfconfidence considered themselves 
responsible for their problems and failures and less attributed their failures to others and finally, were less angry and showed less aggression towards their peers. As a result, despite assertiveness, raising the level of abilities and creating self-confidence decreased the level of aggression in adolescents significantly (7). Crothers et al. (2009) investigated aggression causes among 629 female students and concluded that aggression has a positive relationship with individuals' personality characteristics. Aggressive behavior is seen more among hasty, petulant and domineering and competitive individuals, as a result the amount of aggression can be decreased among students by teaching compatibility, decrease anxiety, creating a sense of friendship and cooperation (8). Vallance, Dunn, and Dunn (2006) showed that increased perfectionism orientation is associated with increased competitive characteristic anger. A comparison of angry responses of athletes with low, medium and high perfectionism levels showed that athletes with high levels of perfectionism compared with athletes with low and medium levels of perfectionism had higher levels of anger over mistakes. Also athletes showed higher level of anger over personal mistakes in high critical situations to low critical situations (9). Aghabarary, VarvaniFarahani, and Mohammadi (2009) in his studies concluded that in nursing care, good communication plays an important role in attracting clients and customers' satisfaction. The findings showed that the average scores given by a nurse to barriers related to a patient was 3.24 and the average scores given by a patient to barriers related to a nurse was 2.8, while common barriers between a nurse and patient was reported as the minimum cause of nurse-patient communication problems (10). Naser et al. (2014) showed that a significant difference was found in overall encroachment and anger, but a significant difference was observed between the two groups in physical aggression (11). Hill (2013) showed that $2 \times$ 2 model for some but not all presents all symptoms of mutual exhaustion of perfectionism aspects in athletes' occupational exhaustion (12). Nazari, Homayuni, and Yektayar (2013) showed a positive and significant relationship is found between organizational justice skills and organizational change understanding (13). As seen in the background of the study, few researches have been found to investigate the relationship between aggression and perfectionism with communication skills' components. Therefore, research in this field can help managers and lifeguards to select an appropriate behavioral model in relation to their working environments. Additionally, studies that have investigated the relationship between aggression and perfectionism with communication skills and their aspects in athletes of other sports fields reached inconsistent research results; for this reason, the present study investigates the relationship between aggression and perfectionism with communication skills of male lifeguards in Tehran.

\section{MATERIALS AND METHODS}

The present study in terms of data collection was correlational, regarding purpose was applied, in terms data collection time it was sectional and regarding data collection method it was a field study.

Participants. The population sample for the study was 300 male lifeguards who worked in the spring of 2014 in pools of Tehran and participated in Pre- Lifeguards courses based on Lifeguard Federation documents. The statistical sample was based on the simple random technique and based on Morgan Table 169 persons were selected as study sample..

Tools. Data collection tools used for the study include: Buss and Perry's Aggression Questionnaire (14), with 29 questions and a reliability coefficient of $78 \%$; Positive and 
negative perfectionism questionnaire (TerryShort et al., 1995) (15), a 40-question test with 20 items each assigned to positive and negative perfectionism and; Communication skills' questionnaire by Stacey et al. (16), developed in 1990, with three components (verbal, listening and feedback skills) consisting of 6 questions each.

Statistical Analysis. In order to describe study variables, descriptive statistics indices such as mean, median, frequency, frequency percentage and diagrams were used. Kolmogorov-Smirnov test and Pearson's correlation coefficient were used to determine data normal distribution.

\section{RESULTS}

The results of the descriptive study show that: for age, the highest frequency (95\%) was observed in 20 to 30 years old group. For lifeguard card degree, the highest card degree frequency 98 percent was observed in grade 2. For marital status of lifeguards, the highest frequency of 53 was observed in single lifeguards. As regards work experience, the highest frequency of $54 \%$ was observed in the 8 years old and older group. For the variable educational level, the highest frequency of $71 \%$ was observed in secondary school level. For the variable, history of the championship, $76 \%$ of lifeguards have provincial championship while for the variable field of study of lifeguards, the highest frequency of 74/ 67 percent was observed for other fields.

There is no relationship between communication skills with aggression and its components of lifeguards $(\mathrm{p}>0.05)$, except with hostility $(r=0.169, \mathrm{p}<0.05)$ (Table 1$)$. In other hand, there is no relationship between aggression with communication skills' components of lifeguards in Tehran (Table $2)$. Also, there is no relationship between positive perfectionism and communication skills' components of lifeguards, except with audio communication skills ( $\mathrm{r}=-0.194$, $\mathrm{p}<0.05$ ) (Table 3).

Table 1. Correlation of communication skills with Aggression and its components

\begin{tabular}{cccccc}
\hline variable & Aggression & $\begin{array}{c}\text { Physical } \\
\text { Aggression }\end{array}$ & $\begin{array}{c}\text { Verbal } \\
\text { Aggression }\end{array}$ & anger & hostility \\
\hline communication skills & 0.091 & 0.043 & 0.039 & 0.044 & $0.169^{*}$ \\
\hline \multicolumn{6}{c}{$*$ significant at $\mathrm{p}<0.05}$.
\end{tabular}

Table 2. Correlation of Aggression with communication skills' components

\begin{tabular}{cccc}
\hline variable & $\begin{array}{c}\text { Verbal } \\
\text { communication skills }\end{array}$ & $\begin{array}{c}\text { Audio } \\
\text { communication skills }\end{array}$ & $\begin{array}{c}\text { Feedback } \\
\text { communication skills }\end{array}$ \\
\hline Aggression & -0.09 & -0.161 & 0.01 \\
\hline
\end{tabular}

Table 3. Correlation of positive perfectionism with communication skills and its components

\begin{tabular}{ccccc}
\hline variable & $\begin{array}{c}\text { communication } \\
\text { skills }\end{array}$ & $\begin{array}{c}\text { Verbal } \\
\text { communication } \\
\text { skills }\end{array}$ & $\begin{array}{c}\text { Audio } \\
\text { communication } \\
\text { skills }\end{array}$ & $\begin{array}{c}\text { Feedback } \\
\text { communication } \\
\text { skills }\end{array}$ \\
\hline $\begin{array}{c}\text { positive } \\
\text { perfectionism }\end{array}$ & -0.051 & 0.079 & $0.194^{*}$ & 0.01 \\
\hline & & $*$ : significant at $\mathrm{p}<0.05$. & &
\end{tabular}

In other hand, there is no relationship between negative perfectionism and communication skills' components of lifeguards (Table 4). 
Table 4. Correlation of negative perfectionism with communication skills and its components

\begin{tabular}{ccccc}
\hline variable & $\begin{array}{c}\text { communication } \\
\text { skills }\end{array}$ & $\begin{array}{c}\text { Verbal } \\
\text { communication } \\
\text { skills }\end{array}$ & $\begin{array}{c}\text { Audio } \\
\text { communication } \\
\text { skills }\end{array}$ & $\begin{array}{c}\text { Feedback } \\
\text { communication } \\
\text { skills }\end{array}$ \\
\hline $\begin{array}{c}\text { negative } \\
\text { perfectionism }\end{array}$ & 0.028 & -0.001 & 0.007 & 0.067 \\
\hline
\end{tabular}

There are no multiple relationships between aggression and perfectionism with communication skills' components of lifeguards (Table 5).

Table 5. Multiple correlation of communication skills with perfectionism and aggression

\begin{tabular}{ccc}
\hline $\mathbf{r}$ & $\mathbf{F}$ & $\mathbf{p}$ \\
\hline 0.015 & 1.007 & 0.392 \\
\hline
\end{tabular}

Dependent variable: communication skills

Predictor variables: perfectionism and aggression

\section{DISCUSSION AND CONCLUSION}

The results of the study showed that there is no relationship between aggression and its subscales with communication skills of lifeguards in Tehran except with hostility and this is consistent with Barati et al., 2012 (17). However, it is not consistent with results of Khenifar et al., 2009 and Çetin, Karabay, and Efe, 2012, (18, 19); and this may possibly be due to different research sample and location. Aggression in a relative study comprehensively is defined as: a behavior that is done with the intention of destroying property or hurting the other person and involves neglecting others health and probably oneself and consequences may be physical or psychological. He then defined violence as a physical act that is carried out with complete disregard for oneself and others health, or to damage other persons or property(ies). Thus, violence and aggression in terms of concept can be considered as actions that are carried out willingly and knowingly to physically or psychologically cause damage to others (20).

Another result of the present study was that there is no relationship between communication skills' components and aggression of lifeguards in Tehran. The result of the present study is consistent with the studies of Nazari, Dadkhah and Yektayar, 2013, and not consistent with results of studies by Gulec and Ertugrul, 2012, and Salmon and Young, $2011(21,22)$. In all models of communication provided, sender, receiver and channel form the main components and the difference between models is in model development and certain aspects presented by message sender or target person, communication channel and feedback (23). Because people with different mental and personality structure use different tactics and techniques of communication, techniques and methods are different in people and can be related to community and cultural factors.

The study also showed that there is no relationship between positive perfectionism and communication skills' components of lifeguards in Tehran except with audio communication skills. This result is consistent with the results of studies by Malekian et al., 2009, (24). However, it is not consistent with results of Hill, 2013, and Stoeber, 2011, (12, 25); and this may possibly be due to different research sample and location. Perfectionists are known as people who tend towards perfection in all 
aspects of life. Perfectionism is known as a tendency towards perfect performance, setting goals at high level and rigorous assessment of oneself. Perfectionists consider the evaluation of others important, are worried of disapproval by others and avoid doing things that are annoying, and thus are guided by other people's disapproval (26).

No relationship is found between perfectionism and communication skills' components of lifeguards in Tehran and is consistent with study by Malekian et al., 2009, (24). A lifeguard refers to an individual who is a master in swimming and has specialized training to maintain and protect the lives of swimmers. Usually as a part of a team, lifeguards may act alone.

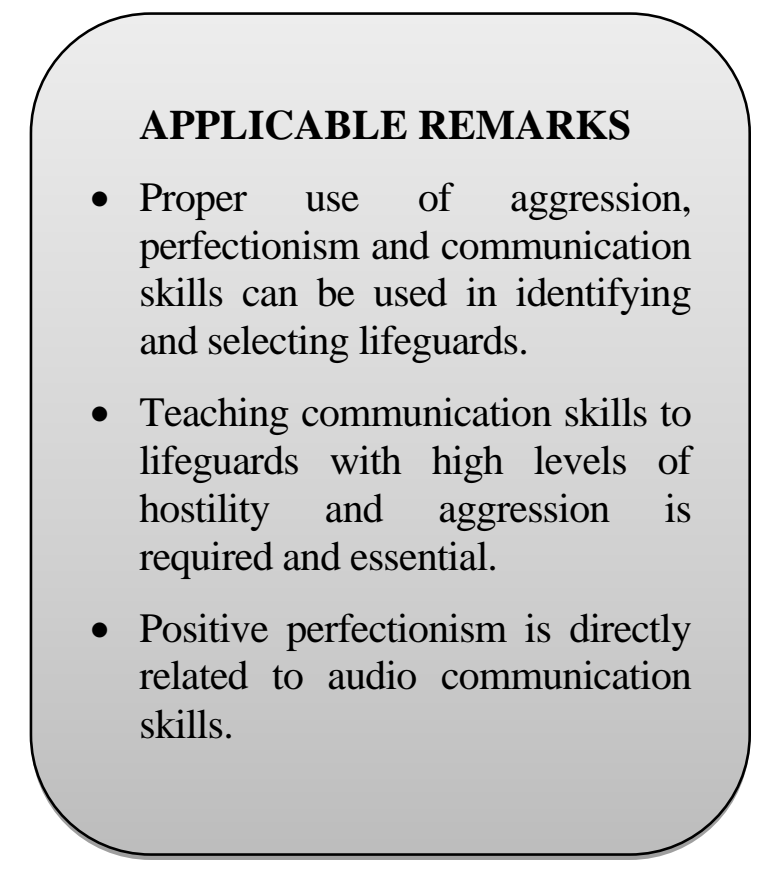

\section{REFFRENCES}

1. Connolly J, Nocentini A, Menesini E, Pepler D, Craig W, Williams TS. Adolescent dating aggression in Canada and Italy: A cross-national comparison. International Journal of Behavioral Development. 2010;34(2):98-105.

2. Strickland BB. The Gale Encyclopedia of Psychology. 2nd ed: Gale Group; 2001. 701 p.

3. Hardy L, Jones JG, Gould D. Understanding psychological preparation for sport: Theory and practice of elite performers. Hoboken, NJ, US: John Wiley \& Sons Inc; 1996. xvi, 346 p.

4. Guo K, Sanchez Y. Work place Communication. In: Borkowski N, editor. Organizational behavior, theory, and design in health care: Jones \& Bartlett Publishers; 2015.

5. Nazari R, Dadkhah I, Yektayar M. The Relationship between communication skills and leadership styles among Isfahan's sport media managers. Communication Management in Sport Media. 2013;1(2):9-13 [Article in Farsi].

6. Ashrafi M, Monjezi F. The effectiveness of communication skills training in reducing aggression among female high school student. Researches of Cognitive and Behavioral Sciences. 2013;3(1):81-98 [Article in Farsi].

7. Ybrandt H, Armelius K. Peer Aggression and Mental Health Problems: Self-Esteem as a Mediator. School Psychology International. 2010;31(2):146-63.

8. Crothers LM, Schreiber JB, Field JE, Kolbert JB. Development and Measurement Through Confirmatory Factor Analysis of the Young Adult Social Behavior Scale (YASB): An Assessment of Relational Aggression in Adolescence and Young Adulthood. Journal of Psychoeducational Assessment. 2009;27(1):17-28.

9. Vallance JK, Dunn JG, Dunn JLC. Perfectionism, anger, and situation criticality in competitive youth ice hockey. Journal of Sport and Exercise Psychology. 2006;28(3):383.

10. Aghabarary M, Varvani-Farahani A, Mohammadi I. Barriers to Application of Communicative Skills by Nurses in Nurse-Patient Interaction: Nurses and Patients' Perspective. Iran Journal of Nursing. 2009;22(61):19-31 [Article in Farsi].

11. Naser A, Afshoon F, Mohammadi HR, Tavasoli E, Rafati Fard M, Khalili A. Comparing the dimensions of aggression in adolescent athletes and non-athletes divorced families. European Journal of Experimental Biology. 2014;4(1):452-5.

12. Hill AP. Perfectionism and burnout in junior soccer players: a test of the $2 \times 2$ model of dispositional perfectionism. J Sport Exerc Psychol. 2013;35(1):18-29.

13. Nazari R, Homayuni Za-N, Yektayar M. Relationship between communication skills and organizational justice with sport managers' perception of organizational change. European Journal of Experimental Biology. 2013;3(3):190-4.

14. Buss AH, Perry M. The aggression questionnaire. J Pers Soc Psychol. 1992;63(3):452-9.

Khodayari, A., Hadavi, F., Barzegar, M. J. Mohammadi. (2015). Ann Appl Sport Sci, 3(3): 35-42. 
15. Terry-Short LA, Owens RG, Slade PD, Dewey ME. Positive and negative perfectionism. Personality and Individual Differences. 1995;18(5):663-8.

16. Stacey PC, Fortnum HM, Barton GR, Summerfield AQ. Hearing-impaired children in the United Kingdom, I: Auditory performance, communication skills, educational achievements, quality of life, and cochlear implantation. Ear and hearing. 2006;27(2):161-86.

17. Barati M, Moeini B, Samavati A, Salehi O. Assessment of Communication Skills Level among Medical College Students: Verbal, Listening, and Feedback Skills. Journal of Nursing and Midwifery Urmia University of Medical Sciences. 2012;10(2):0- [Article in Farsi].

18. Çetin M, Karabay ME, Efe MN. The Effects of Leadership Styles and the Communication Competency of Bank Managers on the Employee's Job Satisfaction: The Case of Turkish Banks. Procedia - Social and Behavioral Sciences. 2012;58:227-35.

19. Khenifar H, Jandaghi GR, Shariati F, Zarvandi N. Reviewing the Communicative Role of Effective Listening And Commitment. Journal of Research in Human Resources Management. 2009;1(3):147-70 [Article in Farsi].

20. Kerr JH, Kelly N. Aggression in women's hockey. British Journal of Physical Education. 1982;13(5):146.

21. Gulec S, Ertugrul A. Examination of Teacher Candidates' Communication Skills Accordıng to Different Variables. Procedia - Social and Behavioral Sciences. 2012;46:5640-5.

22. Salmon P, Young B. Creativity in clinical communication: from communication skills to skilled communication. Medical education. 2011;45(3):217-26.

23. Bean JC, Birge JR. Reducing Travelling Costs and Player Fatigue in the National Basketball Association. Interfaces. 1980;10(3):98-102.

24. Malekian M, Bahabadi., Mohseni H, Zonozi., Keshavarz M. Relationships Between Perfectionism and SelfEsteem in Scientific and Athletic Elites and Non-Elites in Tehran City. Knowledge \& Research in Applied Psychology. 2009;0(41):127-47 [Article in Farsi].

25. Stoeber J. The dual nature of perfectionism in sports: Relationships with emotion, motivation, and performance. International Review of Sport and Exercise Psychology. 2011;4(2):128-45.

26. Azizi S, Nikbakhsh R. The relationship between perfectionism and burnuot among physically disabled elite athletes. Scientific Journal Management System. 2012;9(34):157-67 [Article in Farsi].

Khodayari, A., Hadavi, F., Barzegar, M. J. Mohammadi. (2015). Ann Appl Sport Sci, 3(3): 35-42. 


\section{تازههاى علوم كاربردى ورزش \\ مقاله كوتاه

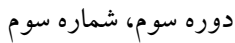

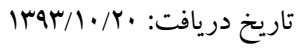

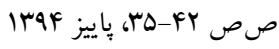

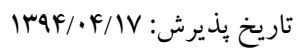 \\ ارتباط مهارتهاى ارتباطى با يرخاشَّرى و كمالَّرايى

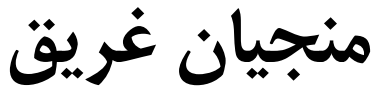 \\ 'عباس خدايارى، 'فريده هادوى، "محمدجواد برزَّر محمدى" \\ ا. استاديار كروه مديريت ورزشى، دانشكده تربيتبدنى و علوم ورزشى، دانشگاه آزاد اسلامى، واحد كرج، كرج، ايران. ז. دانشيار مديريت ورزشى، گروه تربيتبدنى و علوم ورزشى، دانشگاه آزاد اسلامى، واحد اسلامشهر، اسلامشهر، ايران. r. كارشناس ارشد مديريت ورزشى، دانشكده تربيتبدنى و علوم ورزشى، دانشخاه آزاد اسلامى، واحد كرج، كرج، ايران.}

جكيده

هدف از اجراى تحقيق حاضرتعيين ارتباط بين يرخاشكرى وكمالرَايى با مهارتهاى ارتباطى منجيان غريق مرد شهر تهران بود. به همين

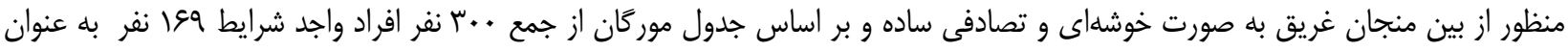

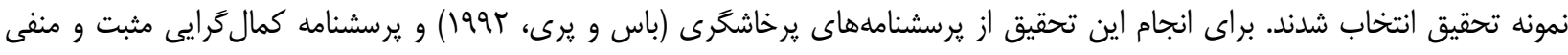

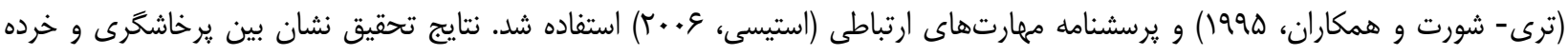

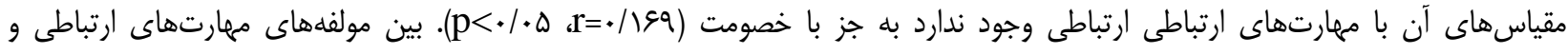
يرخاشكرى ارتباط وجود ندارد. بين كمال

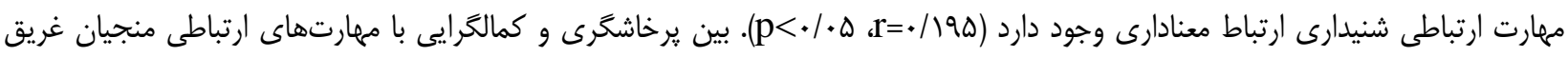

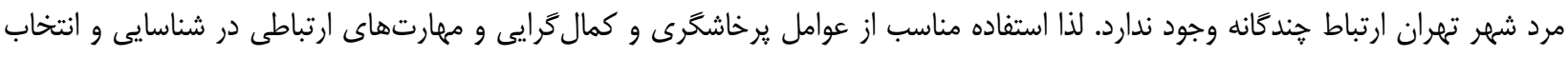
منجيان غريق مفيد مىباشد. وازَّان كليدى: برخاشَّى، كمال كرايى، مهارتهاى ارتباطى، منجيان غريق. 